ISSN 1392-3196 / e-ISSN 2335-8947

Zemdirbyste-Agriculture, vol. 104, No. 3 (2017), p. 249-258

DOI 10.13080/z-a.2017.104.032

\title{
Salt-induced changes in the antioxidant system and viability of oilseed rape
}

\author{
Dušica JOVIČIĆ ${ }^{1}$, Dubravka ŠTAJNER ${ }^{2}$, Boris POPOVIĆ ${ }^{2}$, Ana MARJANOVIĆ-JEROMELA ${ }^{1}$, \\ Zorica NIKOLIĆ ${ }^{1}$, Gordana PETROVIĆ ${ }^{1}$, Ružica ŽDERO-PAVLOVIĆ ${ }^{2}$ \\ ${ }^{1}$ Institute of Field and Vegetables Crops \\ Maksima Gorkog 30, Novi Sad, Serbia \\ E-mail: dusica.jovicic@nsseme.com \\ ${ }^{2}$ University of Novi Sad \\ Trg Dositeja Obradovića 8, Novi Sad, Serbia
}

\begin{abstract}
This work was aimed to investigate the effect of salt $(\mathrm{NaCl})$ stress on three oilseed rape (Brassica napus L.) cultivars: 'Banacanka', 'Jasna' and 'Kata'. The following parameters were determined: antioxidant enzymes superoxide dismutase (SOD) and guaiacol peroxidase (GPX), reduced glutathione (GSH) quantity, lipid peroxidation (LP) intensity, radical-scavenging capacity (DPPH-RSC), hydroxyl radical scavenging ('OH radicals) and ferric reducing antioxidant power (FRAP). Seed viability was determined using the standard laboratory test for germination as well as the seed accelerated aging test measuring the germination, shoot and root length. The plants were subjected to three salt treatments: $0,100,150$ and $200 \mathrm{mmol} \mathrm{dm}^{-3} \mathrm{NaCl}$ for 7 days. All three cultivars responded with an increase of lipid peroxidation in seedlings and with a decrease of GPX activity. 'Banacanka' was found to be the most vulnerable cultivar, with an increase of $237 \%$ of LP intensity in comparison to the control at the highest $\mathrm{NaCl}$ concentration. The induction of the SOD activity was observed for all three cultivars by different $\mathrm{NaCl}$ concentrations. The antioxidant capacity measured by FRAP, DPPH-RSC and ${ }^{\circ} \mathrm{OH}$ radicals was also induced, especially FRAP at the highest concentration in the cultivar 'Jasna' (by 282\%). Germination, shoot and root length decreased for all investigated cultivars. Our results showed that cultivar 'Jasna' is the most adapted to salt stress because of the highest SOD activity and accumulation of antioxidants. Furthermore, this research suggests that some of the antioxidant parameters can be useful biochemical markers for the selection of oilseed rape tolerant cultivars under the conditions of salinity.
\end{abstract}

Key words: accelerated aging, antioxidant enzymes, Brassica napus, germination, lipid peroxidation, salt stress.

\section{Introduction}

Salinity is an important environmental factor that can severely inhibit plant growth and reduce yields of crops. High salt concentration plays a primary role in soil degradation causing significant yield reduction in a large number of crops. Moreover, during the last decades, the problem of salinity has been growing due to the reduced availability of fresh water, which has led to a high level use of inadequate water with high salt content in agricultural production (Shahbaz, Ashraf, 2013).

Salinity has a negative effect on plant growth by generating an osmotic potential in the environment that prevents normal water uptake. The second but no less important negative effect is the toxicity of excessive amounts of sodium ions, which leads to the lack of calcium and potassium and an imbalance of other nutrients. Also, the increased concentration of chloride ions causes necrotic symptoms of toxicity due to the negative impact on the production of chlorophyll, thus significantly reducing growth and water use efficiency in plants (Hasanuzzaman et al., 2013). In other words, plant growth responses under saline conditions occur in two phases: 1) osmotic response, which is characterized by the reduction in growth caused by salt ions in the root zone, and 2) salt-specific response, which usually implies additional reduction in growth caused by toxic levels of salt ions in plant cells (Munns, 2005). As a consequence of these primary effects, salt stress also induces secondary effects such as oxidative damage and nutritional imbalance (Rameeh et al., 2012). In order to cope with negative effects of ionic stress, plants that grow on saline soils have developed different mechanisms (Turkan, Demiral, 2009).

Please use the following format when citing the article:

Jovičić D., Štajner D., Popović B., Marjanović-Jeromela A., Nikolić Z., Petrović G., Ždero-Pavlović R. 2017. Salt-induced changes in the antioxidant system and viability of oilseed rape. Zemdirbyste-Agriculture, 104 (3): 249-258 DOI 10.13080/z-a.2017.104.032 
Many studies have shown that the antioxidant defence system plays a crucial role when plants start to be tolerant to salinity. It has been proven that plant species tolerant to salt increase the antioxidant enzyme activities and a number of non-enzymatic antioxidants in order to protect them from stressful conditions, whereas this cannot be observed in non-salt tolerant species (Turkan, Demiral, 2009).

An important step in crop production in adverse environmental conditions is the selection of high-quality seeds. In addition to the seed gerination, as the most important parameters of quality seeds, quality evaluation is often based on seed viability testing. The seed viability or seed vigour is a set of characteristics that identify the activity and behaviour of seed lot of commercially acceptable germination in the different environmental conditions. This indicator does not show just the percentage of viable seeds in the sample, it also reflects the ability of seeds to establish normal seedlings/plants in unfavourable growing conditions that may occur in a field (ISTA, 2015). Considering the fact that the seed vigour depends on many factors, it is assumed that the cultivars which are better able to achive high seed viability can show more efficient tolerance to stress conditions, such as salinity.

Nowadays, oilseed rape is the most important plant of moderate climates and the areas where it is grown occupy the third place among oil crops in the world (FAO, 2013). Oilseed rape is grown primarily for its seed that is high in protein and oil. This species has no particular requirements regarding soil type and many authors (Athar et al., 2009; Banuelos et al., 2013) believe that this plant species is moderately tolerant to salt stress and can be grown on soils with higher salt contents. Therefore, it is often referred to as the crop of marginal lands (Smith et al., 2013). However, the tolerance of oilseed rape to salinity depends on many factors, primarily on cultivars and stages of development.

Therefore, in the present research, the antioxidant status of seedlings from three oilseed rape cultivars: 'Banacanka', 'Jasna' and 'Kata', and the seed viability were studied for a better understanding how salt stress affects the antioxidant system in seedlings and also the mechanisms that enable tolerance to this type of stress.

\section{Material and methods}

The experiment was conducted with three oilseed rape (Brassica napus L.) cultivars: 'Banacanka', 'Jasna' and 'Kata', in 2015-2016.

Seed germination and growth parameters. Seed germination was determined by the standard laboratory method (SLM) to 400 seeds (four replicates of 100 seeds) and is expressed as a percentage (ISTA, 2015). As a medium for germination filter paper was used, moistened with distilled water in control and with three concentrations of $\mathrm{NaCl}-100,150$ and $200 \mathrm{mmol} \mathrm{dm}^{-3}$ (Abdollahi, Jafari, 2012). The incubation period lasted 7 days, after which percentage of germinated seeds was determined evaluating seedlings with all essential structures, as well as the length of shoot and root. Seed viability of oilseed rape was studied by applying vigour test - a test of accelerated aging (AA) test. Seeds were kept in a water bath at $39^{\circ} \mathrm{C}$ and $100 \%$ relative humidity for a period of 72 hours after which 400 seeds in 4 replicates were sown in Petri dishes (Hampton, Tekrony, 1995).
In both tests, the seedlings were moistened with the same amount of $\mathrm{NaCl}$ solution (100, 150 and $200 \mathrm{mmol} \mathrm{dm}^{-3}$ ) during germination period. After seven days, using 10 seedlings from each treatment, growth parameters were determined.

Extraction procedures. One gram of fresh plant material was extracted with $25 \mathrm{ml} 70 \%$ aqueous ethanol $(0.1 \mathrm{M} \mathrm{HCl})$ under $30 \mathrm{~min}$ sonication in an ultrasonic bath. After filtration under vacuum through a sintered glass funnel, extracts were kept refrigerated. These extracts were used for total antioxidant power determination by the ferric reducing antioxidant power (FRAP) method, radical-scavenging capacity (DPPHRSC) and hydroxyl radical scavenging ( ${ }^{\circ} \mathrm{OH}$ radicals). To determine the lipid peroxidation (LP) and antioxidant enzymes, $1 \mathrm{~g}$ of plant material was macerated with $50 \mathrm{ml} 0.1 \mathrm{M} \mathrm{K}_{2} \mathrm{HPO}_{4}$ (pH 7.0) using mortar. Reduced glutathione (GSH) was extracted with $5 \%$ trichloroacetic acid and free proline with $3 \%$ sulphosalicylic acid. After 10 minutes of centrifugation at $4^{\circ} \mathrm{C}$ and $10,000 \mathrm{~g}$, aliquots of the supernatant were used for enzyme and metabolite determinations as outlined below.

Lipid peroxidation (LP) was estimated by thiobarbituric acid, measuring malondialdehyde (MDA) production using a spectrophotometric assay. The colour intensity of the malondialdehyde-thiobarbituric acid complex in the supernatant was measured. The extinction coefficient at $532 \mathrm{~nm}$ of $153,000 \mathrm{~mol}^{-1} \mathrm{~cm}^{-1}$ for the chromophore was used (Ng et al., 2000).

Antioxidant enzymes and reduced glutathione $(G S H)$. The superoxide dismutase (SOD) activity was measured according to Giannopolitis and Ries (1977), by measuring the ability of the enzyme extract to inhibit the photochemical reduction of nitro-blue tetrazolium. Glass test tubes containing the mixture were illuminated with a fluorescent lamp Philips MLL 5000W. Identical tubes, which were not illuminated, were used as blanks. After the illumination for $15 \mathrm{~min}$, the absorbance was measured at $560 \mathrm{~nm}$. One unit of SOD was defined as the enzyme activity which inhibited the photoreduction of nitro-blue tetrazolium to blue formazan by $50 \%$, and SOD activity of the extracts was expressed as SOD units per mg of protein. The guaiacol peroxidase (GPX) activity was measured using the method of Kato and Shimizu (1987). The activity was calculated using the extinction coefficient of $26.6 \mathrm{mM}^{-1} \mathrm{~cm}^{-1}$ at $470 \mathrm{~nm}$ for oxidized tetraguiacol polymer. One unit of GPX activity was defined as the amount of the enzyme extract which consumes $1 \mu \mathrm{mol}$ of $\mathrm{H}_{2} \mathrm{O}_{2} \min ^{-1} \mathrm{mg}_{\text {protein }}{ }^{-1}$. The content of GSH was determined with the Ellman reagent at $412 \mathrm{~nm}$, according to the procedure of Punitha and Rajasekaran (2011).

Ferric reducing antioxidant power (FRAP). Ferric reducing antioxidant capacity was estimated according to the FRAP assay (Benzie, Strain, 1999). The FRAP reagent was prepared by mixing acetate buffer (300 mM pH 3.6), 2,4,6-tripyridyl-s-triazine reagent $(10 \mathrm{mM}$ in $40 \mathrm{mMHCl})$ and $\mathrm{FeCl}_{3} \times 6 \mathrm{H}_{2} 0(20 \mathrm{mM})$ in the ratio of $3: 1: 1$. A sample of $100 \mu \mathrm{l}$ was mixed with $3 \mathrm{ml}$ of working FRAP reagent and absorbance $(593 \mathrm{~nm})$ was measured after 4 minutes. The test was performed at $37^{\circ} \mathrm{C}$. The FRAP value was calculated using the following formula:

FRAP value $=\Delta \mathrm{A}$ sample $(0-4 \mathrm{~min}) / \Delta \mathrm{A}$ standard (0-4 min). 
The $100 \mu \mathrm{M} \mathrm{Fe}^{2+}$ solution was used as a standard; 1 FRAP unit $=100 \mu \mathrm{M} \mathrm{Fe}^{2+}$; total antioxidant capacity was expressed in FRAP units.

Radical-scavenging capacity (DPPH-RSC) assay was based on measurement of the change of the pink colour of 2,2-diphenyl-1-picrylhydrazyl into the yellow colour after reaction with the extract (Espin et al., 2000). Antioxidant capacity is in accordance with the decrease in the absorbance. Each extract $(5,10,2030$ and $40 \mu \mathrm{l}$ ) was mixed with $90 \mu \mathrm{M}$ DPPH in methanol making up to the final volume of $3.0 \mathrm{ml}$. The mixtures were shaken vigorously and were stored in the dark for 30 minutes at room temperature. The decrease of absorbance of the reaction mixtures relative to the control was monitored at $515 \mathrm{~nm}$. Hydroxyl radical scavenging ('OH radicals) was measured by the method of Halliwell and Gutteridge (1989) with minor changes. $200 \mu \mathrm{l}$ of $2.8 \mathrm{mM} 2$-deoxy-2-ribose, $5 \mu \mathrm{l}$ of $70 \%$ aqueous ethanol extract of oilseed rape, $400 \mu \mathrm{l}$ of $200 \mu \mathrm{M} \mathrm{FeCl}_{3}, 1.04$ $\mathrm{mM} \operatorname{EDTA}(1: 1 \mathrm{v} / \mathrm{v}), 200 \mu \mathrm{H}_{2} \mathrm{O}_{2}(1.0 \mathrm{mM})$ and 200 $\mu 1$ ascorbic acid $(1 \mathrm{mM})$ were mixed to form a reaction mixture. After an incubation period of one hour at $37^{\circ} \mathrm{C}$, the extent of deoxyribose degradation was measured by the thiobarbituric acid (TBA) reaction. Afterward, the reaction mixture was kept boiling with $1.5 \mathrm{ml}$ of $2.8 \%$ tri-chloroacetic acid (TCA) for 20 minutes at $100^{\circ} \mathrm{C}$. RSC was calculated by the following equation:

$$
\mathrm{RSC}=\left(\left(\mathrm{A}_{0}-\mathrm{A}_{1}\right) / \mathrm{A}_{0}\right) \times 100 \text {, }
$$

where $A_{0}$ is the control, $A_{1}$ - the sample solution absorbance. Removal capacity of $\cdot \mathrm{OH}$ radicals of the extract was expressed as a percentage of inhibition of deoxyribose degradation (\%I).

Statistical analysis. Statistical significance was performed using a one-way analysis of variance (ANOVA) followed by comparisons of means using Duncan's multiple range test $(P<0.05)$. The correlation analysis and ANOVA were done using the software STATISTICA, version 10 (StatSoft Inc., USA). Because of the great differences in the absolute values of the particularly investigated parameters and for the sake of their mutual comparison, the results were expressed as the percentage of the control.

\section{Results and discussion}

Highly significant differences were found for all main sources of variation (salt stress level, cultivar) and interaction between them for SOD activity, GPX activity, LP intensity, DPPH-RSC, ${ }^{\circ} \mathrm{OH}$ radicals and FRAP (Table 1).

Table 1. Analysis of variance of main effects and interactions for oilseed rape cultivars

\begin{tabular}{|c|c|c|c|c|c|c|c|c|c|}
\hline $\begin{array}{l}\text { Source of } \\
\text { variation }\end{array}$ & $\begin{array}{l}\text { SS } \\
\%\end{array}$ & MS & $P$ & $\begin{array}{l}\text { SS } \\
\% \\
\end{array}$ & MS & $P$ & $\begin{array}{l}\text { SS } \\
\% \\
\end{array}$ & MS & $P$ \\
\hline & \multicolumn{3}{|c|}{ SOD } & \multicolumn{3}{|c|}{ GPX } & \multicolumn{3}{|c|}{ LP } \\
\hline Salt stress (S) & 22.5 & 6419.2 & $0.000 * *$ & 43 & 401.7 & $0.000 * *$ & 93.9 & 75718.1 & $0.003 * *$ \\
\hline Cultivar (C) & 35.6 & 1517.1 & $0.000 * *$ & 37.2 & 521.4 & $0.000 * *$ & 2.7 & 3206.4 & $0.000 * *$ \\
\hline $\mathrm{S} \times \mathrm{C}$ & 41.9 & 5961.1 & $0.000 * *$ & 19.8 & 92.3 & $0.000 * *$ & 3.4 & 1366.1 & $0.004 * *$ \\
\hline & \multicolumn{3}{|c|}{ GSH } & \multicolumn{3}{|c|}{${ }^{\circ} \mathrm{OH}$ radicals } & \multicolumn{3}{|c|}{ FRAP } \\
\hline Salt stress (S) & 74.4 & 18.2 & $0.000 * *$ & 90.8 & 464.6 & $0.000 * *$ & 71.9 & 7.1 & $0.003 * *$ \\
\hline Cultivar (C) & 18.1 & 6.6 & $0.004 * *$ & 7.8 & 59.1 & $0.000 * *$ & 9.7 & 1.4 & $0.000 * *$ \\
\hline $\mathrm{S} \times \mathrm{C}$ & 7.5 & 0.9 & $0.001 * *$ & 1.4 & 3.7 & $0.000 * *$ & 18.4 & 0.9 & $0.000 * *$ \\
\hline & \multicolumn{3}{|c|}{ DPPH-RSC } & \multirow{4}{*}{\multicolumn{6}{|c|}{$\begin{array}{l}\mathrm{SS} \text { - sum of squares, MS - mean squares; } \mathrm{SOD}-\text { superoxide dismutase, } \\
\mathrm{GPX} \text { - guaiacol peroxidase, LP - lipid peroxidation intensity, GSH } \\
\text { - reduced glutathione quantity, OH radicals - hydroxyl radical } \\
\text { scavenging, FRAP - ferric reducing antioxidant power, DPPH-RSC - } \\
\text { radical-scavenging capacity; } * *-P<0.01\end{array}$}} \\
\hline Salt stress (S) & 49.3 & 30.6 & $0.000 * *$ & & & & & & \\
\hline Cultivar (C) & 34.3 & 31.9 & $0.000 * *$ & & & & & & \\
\hline $\mathrm{S} \times \mathrm{C}$ & 16.4 & 5.1 & $0.002 * *$ & & & & & & \\
\hline
\end{tabular}

The activity of antioxidant enzymes. The values of $\mathrm{SOD}$ at different $\mathrm{NaCl}$ concentrations varied as following: 187.29-336.29 $\mathrm{U} \mathrm{mg}^{-1}$ ('Banacanka'), 312.64-339.23 U mg-1 ('Jasna') and 277.90-303 $45 \mathrm{U}$ $\mathrm{mg}^{-1}$ ('Kata') of proteins (Fig. 1). In cultivars 'Jasna' and 'Kata' shoots, the activity of this enzyme was gradually increased by increasing the salt stress level. Furthermore, an increase in SOD activity was observed to a concentration of $150 \mathrm{mmol} \mathrm{dm}^{-3} \mathrm{NaCl}$, while it was reduced at the highest concentration. These two cultivars responded in the same manner to the same salt stress level. In contrast, cultivar 'Banacanka' had the highest values at the concentrations of $100 \mathrm{mmol} \mathrm{dm}^{-3} \mathrm{NaCl}$.

Studying the SOD activity in salt-tolerant and salt-sensitive oilseed rape varieties, Jalali-e-Emam et al. (2011) have shown that this enzyme plays an important role when it comes to salinity tolerance. Decreased SOD activity and other antioxidant enzymes at extremely high salt concentrations could be caused by difficult absorption of sufficient amounts of water due to the high concentration of ions in the root zone (Dai et al., 2009). If a plant does not absorb water, the amount of salt in the plant will be reduced which inhibits the function of the antioxidant system. Another possible reason for the decrease in the activity of this enzyme at high levels of salt stress is a lot of toxic $\mathrm{Na}^{+}$ions which affect the generation of a large amount of reactive oxygen species (ROS) that the antioxidant defence system is unable to control. Also, the decrease of the SOD activity indicates that the scavenging activity of this enzyme may be distracted or results in plant adaptation to salt stress (Shahbazi et al., 2011).

The GPX activity in the shoots at different concentrations of $\mathrm{NaCl}$ kept going from: 9.68-21.44 U $\mathrm{mg}^{-1}$ ('Banacanka'), 9.90-14.85 U mg-1 ('Jasna') and 12.83-30.86 U mg-1 ('Kata') of proteins (Fig. 1). When it comes to the cultivars 'Banacanka', 'Jasna' and 'Kata', there was a significant decrease in the GPX activity with 

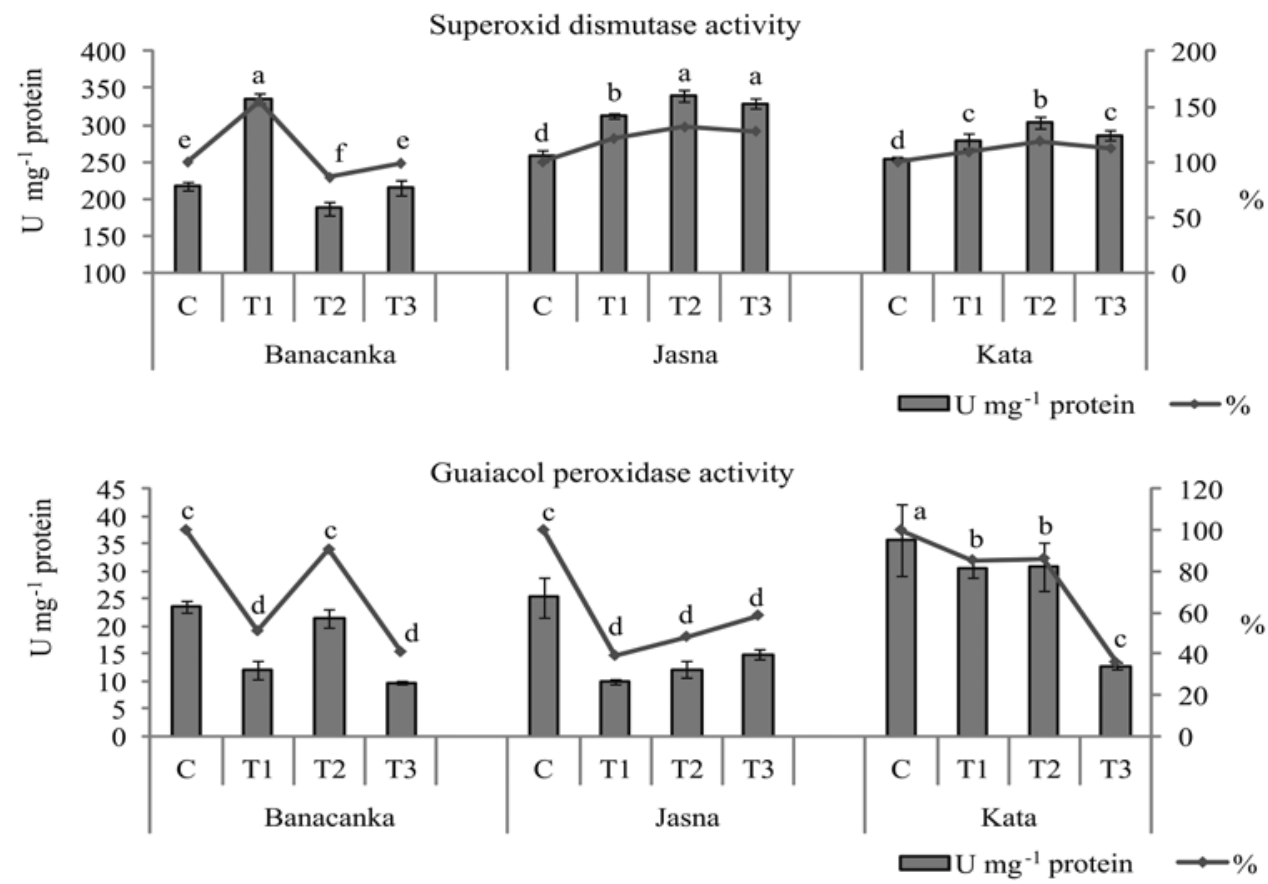

Note. C - control, $\mathrm{T} 1$ - $100 \mathrm{mmol} \mathrm{dm} \mathrm{maCl}^{-3} \mathrm{~N} 2-150 \mathrm{mmol} \mathrm{dm}^{-3} \mathrm{NaCl}, \mathrm{T} 3-200 \mathrm{mmol} \mathrm{dm}{ }^{-3} \mathrm{NaCl}$; means with similar letter are not significantly different, compared by Duncan's multiple comparison test $(P=0.05)$.

Figure 1. Changes in the antioxidant enzymes - superoxid dismutase (SOD) and guaiacol peroxidase (GPX) - activity in oilseed rape cultivars after the treatment with different $\mathrm{NaCl}$ concentrations

a higher intensity of salt stress. The most prominent decrease appeared at the concentration of $200 \mathrm{mmol}$ $\mathrm{dm}^{-3} \mathrm{NaCl}$ in comparison to the control of the following cultivars - 'Kata' (64.17\%) and 'Banacanka' (59.11\%).

As previously noted, salinity leads to the formation of stress conditions which disrupt the system of electron transport by creating a large amount of ROS, which may cause significant damage to cells (Tanou et al., 2009). In these conditions, peroxidases play an important role because they catalyze the reactions in which phenolic substrates are oxidized, while the ROS are reduced to less harmful forms of oxygen. Regulating the availability of $\mathrm{H}_{2} \mathrm{O}_{2}$, peroxidases affect growth or cell elongation, as well as the connection of phenolic components in order to inhibit growth.

Tolerant species or varieties are characterized by increased activities of antioxidant enzymes and in regard to this, a higher SOD activity was found in this experiment in cultivars 'Jasna' and 'Kata'. Similar increase of SOD activity was reported by Zare and Paknyat (2012) in fifteen oilseed rape cultivars, exposed to two levels of salt stress. Our research results confirm that the increased activity of antioxidant enzymes of salttolerant varieties indicate that scavenging of ROS might be a part of the overall adaptive plant strategy in response to stress conditions (Mittal et al., 2012).

Lipid peroxidation (LP). This parameter was predominantly influenced by the salt stress level (93.9\%), while cultivar amounted to $2.7 \%$ and interaction salt stress level $\times$ cultivar to $3.4 \%$ of the total variability.

In all examined cultivars, there was a gradual increase in the intensity of LP with a higher concentration of $\mathrm{NaCl}$. Cultivar 'Banacanka' showed the highest $(237.21 \%)$ increase at the highest salt stress level, while 'Kata' showed the lowest (147.73\%), compared to the control (Fig. 2).

Due to the extremely high vulnerability of lipids to oxidation, the main product of lipid peroxidation-

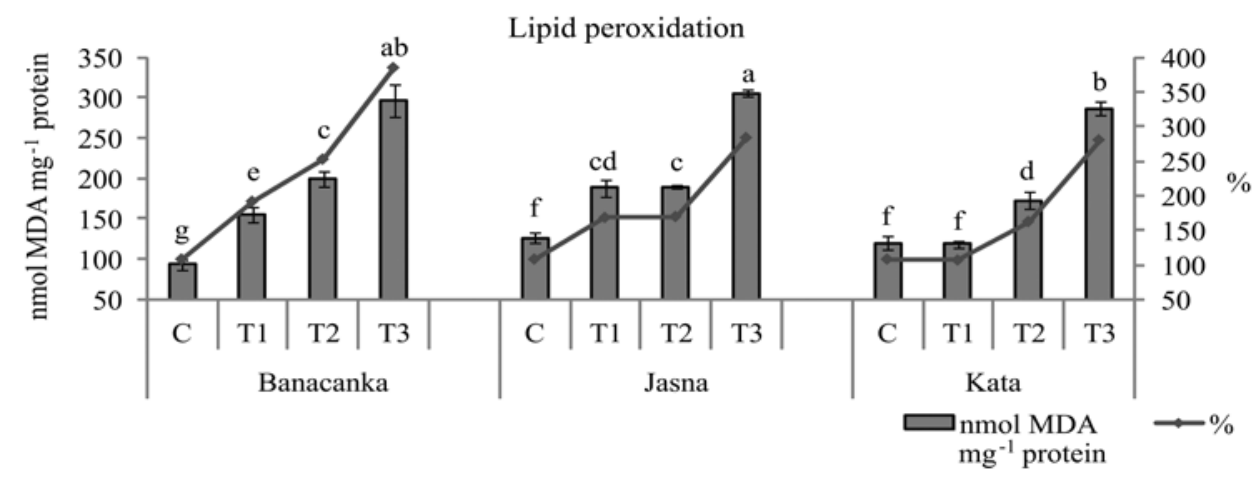

Explanations under Figure 1

Figure 2. Changes in lipid peroxidation (LP) in oilseed rape cultivars after the treatment with different $\mathrm{NaCl}$ concentrations 
MDA could be considered as a potential marker for levels of oxidative stress in vivo (Popovic et al., 2013). Lower values of the LP intensity in salt-tolerant varieties and species indicate that the plants were better protected against oxidative stress in saline conditions (TayefiNasrabadi et al., 2011). Although the capacity of the removal of hydroxyl radicals functions well, the intensity of lipid peroxidase was high in all examined cultivars during exposure to salt stress conditions. A strong negative correlative relationship between ${ }^{\circ} \mathrm{OH}$ radicals and LP was observed in all cultivars: 'Banacanka' $(r=$ $0.87)$, 'Jasna' $(r=0.81)$ and 'Kata' $(r=0.77)$. Such a relationship may indicate the importance of membrane lipids and their peroxidation for normal metabolic process under stressful conditions. The accumulation of ROS in the examined cultivars was inhibited by its enhanced ${ }^{\circ} \mathrm{OH}$ radical-scavenging ability and thus it is protected from lipid peroxidation of membrane systems and oxidative damage under salt stress during germination and early seedling growth. The cultivar 'Kata' showed the highest values of this parameter pointing to intensive lipid degradation and a high level of oxidative stress.

Reduced glutathione (GSH). Like LP intensity, the amount of GSH was predominantly influenced by the salt stress level $(74.4 \%)$, while cultivar amounted to $18.1 \%$ and interaction salt stress level $\times$ cultivar to $7.5 \%$ of the total variability. In all cultivars, this parameter enhanced with the increasing $\mathrm{NaCl}$ concentration. There are no statistically significant differences between the concentrations of 100 and $150 \mathrm{mmol} \mathrm{dm}^{-3} \mathrm{NaCl}$ in cultivars 'Jasna' and 'Kata'. The lowest value was observed in cultivar 'Kata' at all stress levels (Fig. 3).



Explanations under Figure 1

Figure 3. The amount of reduced glutathione (GSH) in oilseed rape cultivars after the treatment with different $\mathrm{NaCl}$ concentrations

GSH is the non-enzymatic ROS scavenging system which directly reacts with free radicals by detoxifying them. Based on these results, it could be suggested that salt stress leads to the increased amounts of GSH in oilseed rape seedlings in different cultivars, and it can be assumed that this parameter contributes to oxidative stress tolerance caused by high concentrations of $\mathrm{NaCl}$. This antioxidant is involved in ROS detoxification, redox signaling and modulation of gene expression and regulation of enzyme activity (Foyer, Noctor, 2009). The importance of glutathione in plant growth and development is reflected in the fact that the reduced synthesis of glutathione is in direct correlation with growth disorders (Vernoux et al., 2000), and also the fact that complete absence of glutathione synthesis causes plant death. Furthermore, the strong negative correlative relationship between the amount of GSH and the percentage of germination at both tests points to an important role of non-enzymatic antioxidants in the process of adapting to salinity. These results indicate that changes in the GSH content and thus in the glutathioneacrobats cycle lead to the reduction of oxidative damage, improving tolerance to oxidative stress.

Hydroxyl radical scavenging ( $\mathrm{OH}$ radicals). The value of $\mathrm{OH}$ radical scavenging activities at different concentrations of $\mathrm{NaCl}$ ranged as following: 53.11-59.60\% ('Banacanka'), 50.53-56.02\%I ('Jasna'), 46.52-56.25\%I ('Kata') (Fig. 4).

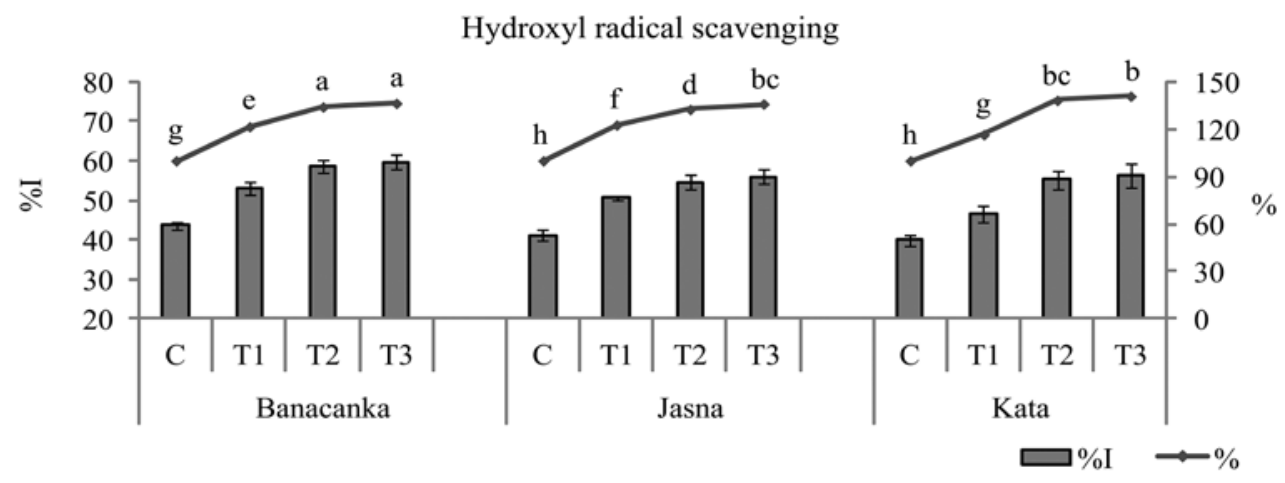

Explanations under Figure 1

Figure 4. Hydroxyl radical scavenging ( ${ }^{\circ} \mathrm{OH}$ radicals) in oilseed rape cultivars after the treatment with different $\mathrm{NaCl}$ concentrations 
In all cultivars, there was an increase in the capacity of $\mathrm{OH}$ radicals scavenging activities with increasing concentrations of $\mathrm{NaCl}$, but the difference between the concentrations of 150 and $200 \mathrm{mmol} \mathrm{dm}^{-3}$ was not statistically significant. Environmental stresses, including high salinity and drought, cause increased production and accumulation of ROS leading to oxidative stress and disturbance of normal cellular activity (Tanou et al., 2009). One of the most toxic ROS is the hydroxyl radical. In addition, there is no enzymatic reaction that can directly eliminate this highly reactive and toxic radical. Therefore, its accumulation inevitably leads to a reaction that damages the thylakoid membrane and disturbs the functions of photosynthetic apparatus (Cruz de Carvalho, 2008). Due to the high reactivity of ${ }^{\circ} \mathrm{OH}$ radicals in biological systems, the ability of plant cells to neutralize the reactive radicals is of great importance for protection against oxidative stress. The data showed that all oilseed rape cultivars have the extensive capability to neutralize ${ }^{\circ} \mathrm{OH}$ radicals and that this capacity rises along with increasing levels of stress.

Ferric reducing antioxidant power (FRAP). In all cultivars, the highest value of this parameter was at the highest stress level, while 'Jasna' showed the most significant increase $(281.85 \%)$, compared to the control (Fig. 5).

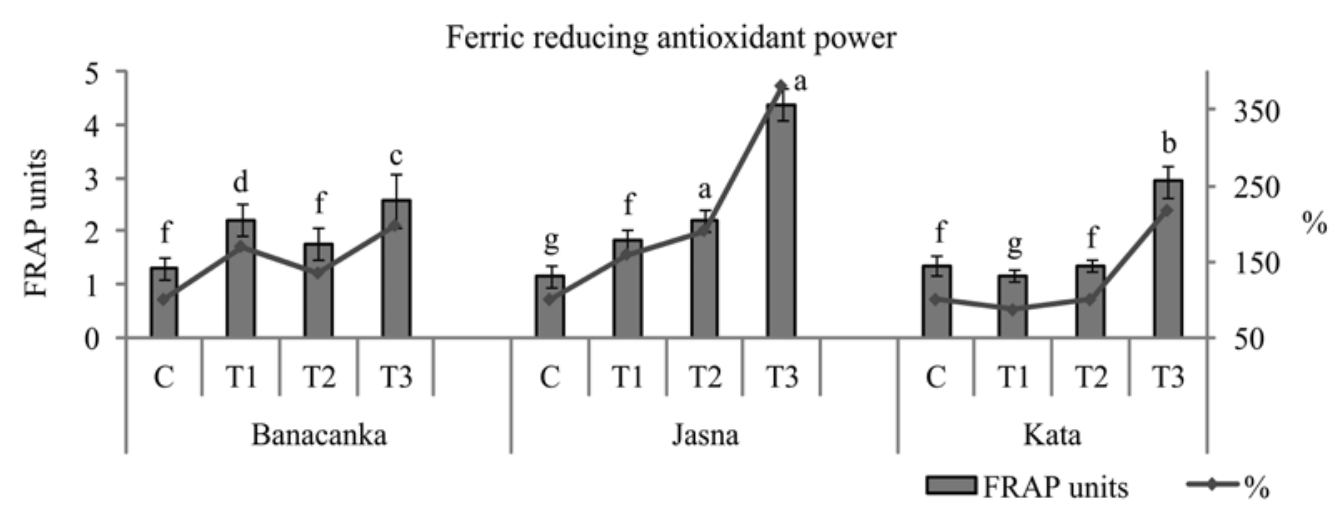

Explanations under Figure 1

Figure 5. Ferric reducing antioxidant power (FRAP) in oilseed rape cultivars after the treatment with different $\mathrm{NaCl}$ concentrations

Cultivars 'Banacanka' and 'Jasna' showed an increase in the total antioxidant activity at all $\mathrm{NaCl}$ concentrations, compared to the control, while in 'Kata' this indicator was the lowest at the lowest level of stress. The obtained results indicated that the level of salt stress affected the total antioxidant activity in all cultivars. Since it is proved that an efficient antioxidant system can provide better protection against oxidative stress (Kumar et al., 2011; Stajner et al., 2013), the total antioxidant activity expressed in FRAP units has an important practical significance in the ranking of varieties and species according to tolerance to oxidative stress. In cultivar 'Banacanka' the increased value of FRAP was at the lowest $\mathrm{NaCl}$ concentrations, which may indicate that small amounts of $\mathrm{NaCl}$ have a stimulating effect on the activation of the antioxidant defence system.
Radical-scavenging capacity (DPPH-RSC). This parameter was mostly under the influence of the salt stress level $(49.3 \%)$ and cultivar $(34.3 \%)$. As indicated in Figure 6, there was observed a gradual increase of DPPH scavenging activity with increasing concentrations of $\mathrm{NaCl}$ in cultivar 'Banacanka', and the increase was most significant at the concentration of $200 \mathrm{mmol} \mathrm{dm}^{-3}$. In cultivar 'Jasna', the decrease of activity of this parameter was observed at the lowest level of stress, but at the maximum concentration, there is an increase of $55.57 \%$ in comparison to the control. In cultivar 'Kata', this parameter decreased at the lowest and moderate level of stress.

DPPH-RSC scavenging activity is determined by an indirect method which is based on the ability of the extract to reduce the activity of a moderately stable

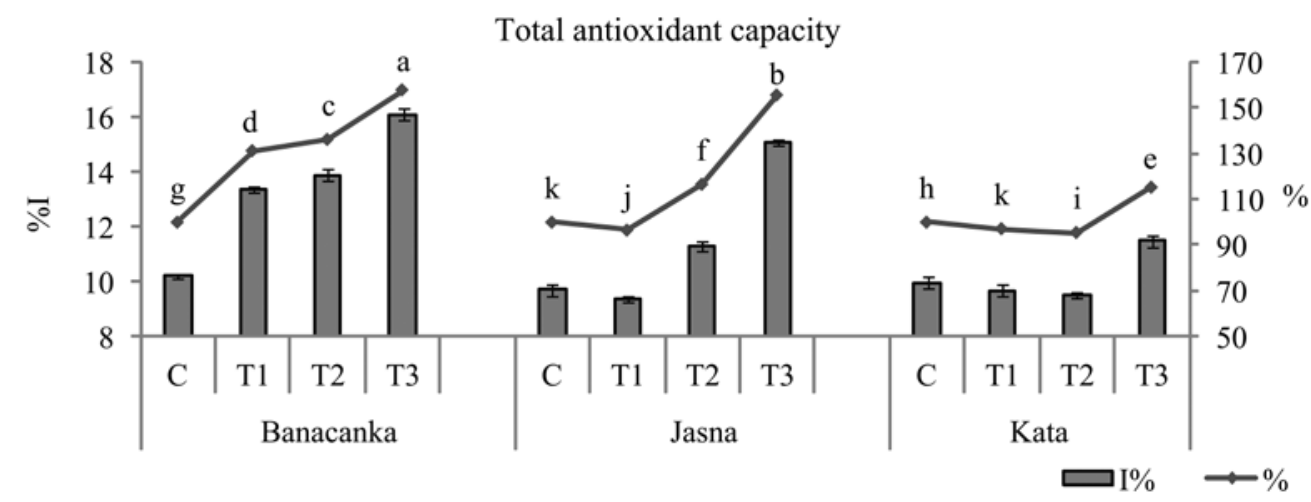

Explanations under Figure 1

Figure 6. Radical-scavenging capacity (DPPH-RSC) in oilseed rape cultivars after the treatment with different $\mathrm{NaCl}$ concentrations 
DPPH radical by an exchange of hydrogen atoms between the radicals and an antioxidant (Prakash, 2001). In salt stress conditions, cultivars 'Banacanka' and 'Jasna' compared to 'Kata' showed a better scavenging ability. These results may indicate that higher concentrations of $\mathrm{NaCl}\left(150 \mathrm{mmol} \mathrm{dm}^{-3}\right)$ affect the imbalance between ROS generation and the process of neutralization. This is corroborated by the results of reduced LP and increased SOD activity in these two cultivars. On the other hand, Miljus-Djukic et al. (2013) reported that plants have a higher capacity to resist salt stress at high $\mathrm{NaCl}$ concentrations such as 150 and $200 \mathrm{mmol}$ $\mathrm{dm}^{-3}$ if the change in DPPH-RSC activity does not vary significantly with increasing stress level, as it is the case with cultivar 'Kata'.

Germination. Highly significant differences were stated only for salt stress level while cultivar and interaction between these two main sources of variation were not significant for seed germination at both (SLM and AA) tests (Table 2).

Table 2. Analysis of variance ( $A N O V A)$ of main effects and interactions for oilseed rape cultivars (germination, shoot length and root length) for SLM and AA tests

\begin{tabular}{cccc|ccc|ccc}
\hline Source of variation & SS (\%) & MS & $P$ & SS (\%) & MS & $P$ & SS (\%) & MS & $P$ \\
\hline \multicolumn{9}{c|}{ Standard laboratory method (SLM) } \\
\hline \multicolumn{3}{c|}{ germination } & \multicolumn{3}{c}{ shoot length } & \multicolumn{3}{c}{ root length } \\
\hline Salt stress level (S) & 94.6 & 299.0 & $0.000^{* *}$ & 95.9 & 2140.5 & $0.000^{* *}$ & 88.0 & 7692.7 & $0.000^{* *}$ \\
Cultivar (C) & 3.8 & 18.2 & 0.111 & 3.7 & 124.2 & $0.004^{* *}$ & 7.3 & 955.8 & $0.000^{* *}$ \\
S $\times$ C & 1.6 & 2.5 & 0.911 & 0.4 & 4.1 & 0.967 & 4.7 & 204.6 & $0.002^{* *}$ \\
\hline \multicolumn{8}{c|}{ Accelerated aging (AA) test } \\
\hline \multicolumn{8}{c|}{ germination } \\
\hline Salt stress level (S) & 87.8 & 342.7 & $0.000^{* *}$ & 98.0 & 4623.2 & $0.000^{* *}$ & 95.3 & 9712.7 & $0.000^{* *}$ \\
Cultivar (C) & 6.9 & 40.1 & 0.032 & 0.4 & 31.8 & 0.119 & 2.9 & 450.7 & $0.000^{* *}$ \\
S $\times$ C & 5.3 & 10.4 & 0.432 & 1.6 & 38.0 & 0.033 & 1.8 & 92.7 & $0.007^{* *}$ \\
\hline
\end{tabular}

$\mathrm{SS}$ - sum of squares, MS - mean squares; $* *-P<0.01$

The results of this experiment show that the increasing of concentrations of $\mathrm{NaCl}$ in germination media significantly decrease seed germination of oilseed rape in both (SLM and AA) tests (Fig. 7). In all cultivars, significant differences in germination were not observed between the controls and the lowest salt concentration $\left(100 \mathrm{mmol} \mathrm{dm}^{-3} \mathrm{NaCl}\right)$, but a significant decrease occurred only at higher salt concentrations $\left(150-200 \mathrm{mmol} \mathrm{dm}^{-3}\right.$ $\mathrm{NaCl}$ ). In cultivar 'Banacanka' there was noticed the biggest difference between the control and the highest concentration $(14.6 \%$ in SLM, $16.8 \%$ in AA test).
However, after the accelerated aging the highest (9.8$13.1 \%$ ) seed decay was observed in cultivar 'Jasna' at all $\mathrm{NaCl}$ concentrations, compared to the control. These results confirm the classification in which oilseed rape is considered moderately tolerant to salinity. Tavakkoli et al. (2010) suggest that very often it is not known whether the reduction in seed germination at high salt levels is caused primarily by disturbances in osmotic regulation, which leads to difficulties in the absorption of water in saline conditions, or is the result of toxic effects of $\mathrm{Na}^{+}$ and $\mathrm{Cl}^{-}$ions which also can be manifested.



Explanations under Figure 1

Figure 7. Seed germination at the standard laboratory method (SLM) and the accelerated aging (AA) test in oilseed rape cultivars after the treatment with different $\mathrm{NaCl}$ concentrations

Similar relations between the cultivars, but lower germination were observed at the AA test. Performing this test seeds absorb water from the humid environment and thereby the moisture content in seeds increases, while the high temperature leads to accelerated aging and deterioration of seeds simultaneously (ISTA, 2015).

In all the cultivars, there was a significant correlation between seed germination and all parameters of antioxidative status, except GPX activity, confirming the activation of the antioxidant defence mechanism in the saline conditions during germination process. The largest decrease in germination in stressed conditions in both tests was observed in cultivar 'Jasna'.

Seedling growth. In order to examine the influence of different $\mathrm{NaCl}$ concentrations on morphological changes of seedlings, growth parameters 
were determined. The most important source of variation for shoot length was salt stress level while effect of cultivar was statistically significant only at the SLM and salt stress level $\times$ cultivar interaction at AA test (Table 2).
The results of seedling length show that at lower $\mathrm{NaCl}$ concentrations both shoots and roots still have the capacity to cope with salt stress, whereas at higher concentrations, there is a significant occurrence of damage and necrosis of tissue (Fig. 8).
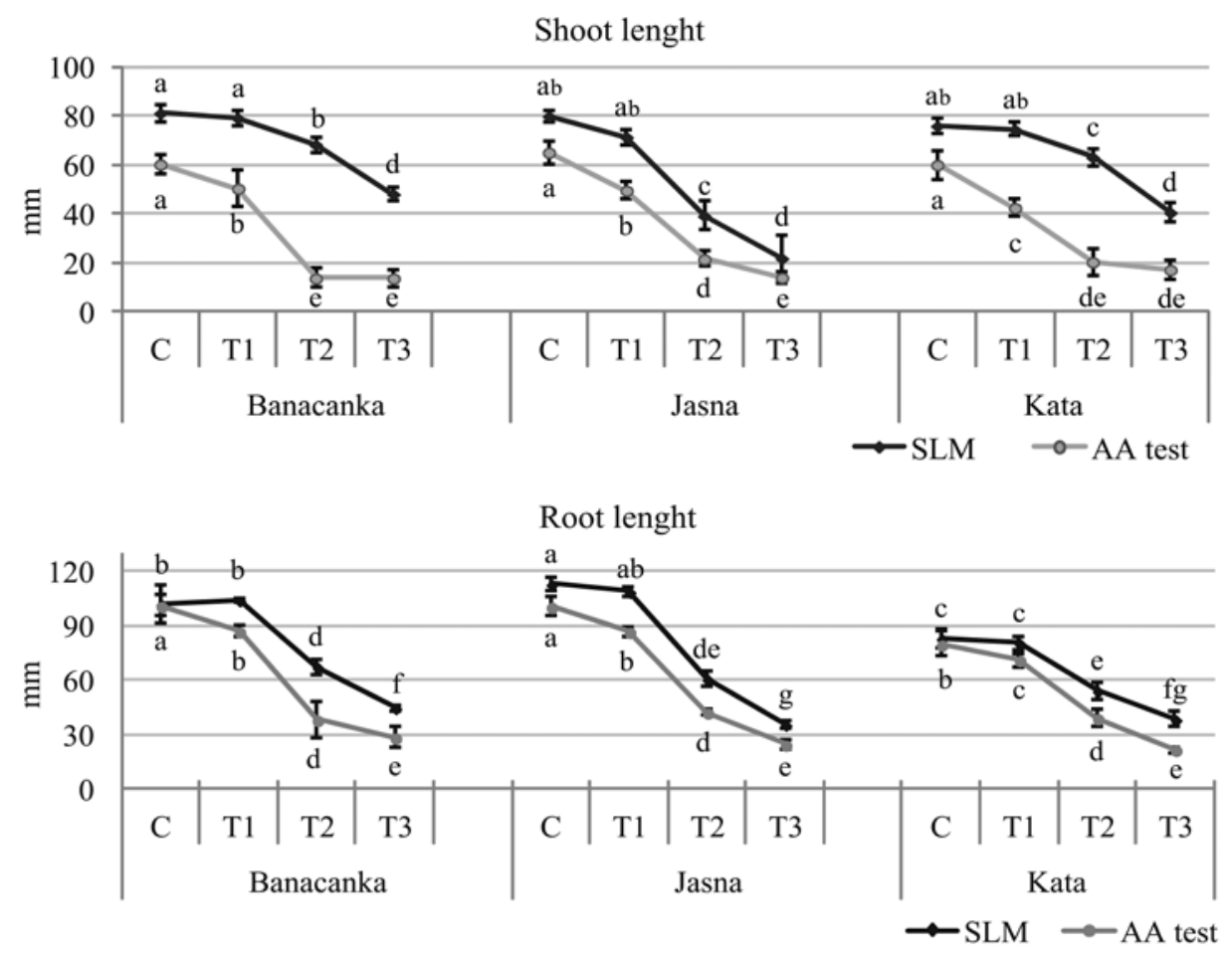

Explanations under Figure 1

Figure 8. Shoot and root length at the standard laboratory method (SLM, above) and the accelerated aging (AA) test (below) in oilseed rape cultivars after the treatment with different $\mathrm{NaCl}$ concentrations

Cultivar 'Jasna' had the lowest values of shoot growth at SLM and the highest value at AA test in control. Also, in this cultivar, there was the largest reduction at the concentration of $150 \mathrm{mmol} \mathrm{dm}^{-3} \mathrm{NaCl}(25.1 \%$ at SLM, $67.3 \%$ at AA test) and at the concentration of $200 \mathrm{mmol}$ $\mathrm{dm}^{-3} \mathrm{NaCl}$ (55.3\% at SLM, 78.7\% at AA test). In cultivar 'Kata', root length was lowest at all concentrations of $\mathrm{NaCl}$ in both tests, while in 'Jasna' there were observed the highest values of this parameter only in SLM. The obtained results in the AA test were significantly lower than the values obtained at SLM in the control and all salt treatments. A significant reduction in growth at all $\mathrm{NaCl}$ concentrations indicates that the seeds which have been exposed to the accelerated aging treatment are significantly less able to resist even the lowest level of salt stress.

Salinity leads to the reduction in cell division and cell elongation, primarily because of the difficulty to absorb nutrients mostly due to the accumulation of large amounts of reactive oxygen species, inhibition of cellular enzymes, loss of turgor and hormone imbalance which affects plant growth, and later has a negative effect on the production of biomass and yields (Ashraf et al., 2010). Abdel Haleem et al. (2012) have suggested that salinity causes growth reduction in Vigna unguiculata at various $\mathrm{NaCl}$ concentrations (50, 100 and $200 \mathrm{mmol} \mathrm{dm}^{-3}$ ).

Analysing the differences between the shoot and length, depending on the concentration of $\mathrm{NaCl}$, at both tests it was observed that the values were the most similar at the control. These results may suggest that high concentrations of $\mathrm{NaCl}$ were the dominant factor in compared to the other negative factors covered AA test, such as high temperature and humidity.

Plant species and cultivars that have better seed germination and seedling growth under salt stress will be more tolerant to stressful conditions in the later stages (Ashraf, McNeilly, 2004). There was noted a positive correlation between salinity tolerance at seedlings stages and adult plants of Brassica genus (Ashraf, Ali, 2008).

\section{Conclusions}

1. Salt stress level, cultivar, and salt stress level $\times$ cultivar interaction were significant sources of variation for all the analysed parameters: superoxide dismutase (SOD), guaiacol peroxidase (GPX), reduced glutathione (GSH) quantity, lipid peroxidation intensity (LP), radicalscavenging determination (DPPH-RSC), hydroxyl radical scavenging ( ${ }^{\circ} \mathrm{OH}$ radicals) and ferric reducing antioxidant power (FRAP) except for germination and shoot length.

2. Different salt $(\mathrm{NaCl})$ concentrations led to the induction of both enzymatic and non-enzymatic antioxidants in the seedling shoots of oilseed rape. The mechanisms that enable tolerance to salt stress in oilseed rape include increase of LP, GSH and SOD activity while GPX activity was reduced. The antioxidant capacity measured by FRAP, DPPH and ${ }^{\circ} \mathrm{OH}$ radicals was also activated.

3. Although there were clear differences between cultivars, considering the parameters of the antioxidant status under salt stress, $\mathrm{NaCl}$ concentration was a 
predominant source of variation causing the activation of defence mechanisms in seedlings.

4. Salt stress level at the concentrations of 150 and $200 \mathrm{mmol} \mathrm{dm}^{-3} \mathrm{NaCl}$ significantly reduced seed germination rate and seedling growth limiting normal function at the cellular level. 'Jasna' was clearly proved to be the most tolerant cultivar because of the highest SOD activity and accumulation of antioxidants.

5. Testing seed viability complemented with the determination of the antioxidant parameters were shown to be useful indicator for the selection of oilseed rape tolerant cultivars under the conditions of salinity. This fact is especially important considering that the problem of salinity is very complex and that a large number of parameters are responsible for tolerance.

\section{Acknowledgements}

This research results from project TR 31025 "Development of new varieties and production technology improvement of oil crops for different purposes" funded by Ministry of Education, Science and Technological Development of the Republic Serbia.

Received 25012017

Accepted 02062017

\section{References}

1. Abdel Haleem M. A. M., Heba I. M., Zaki M. L., Mogazy M. A. 2012. Pre-exposure to gamma rays alleviates the harmful effect of salinity on cowpea plants. Journal of Stress Physiology and Biochemistry, 8 (4): 199-217.

2. Abdollahi F., Jafari L. 2012. Effect of $\mathrm{NaCl}$ and $\mathrm{KNO}_{3}$ priming on seed germination of canola (Brassica napus L.) under salinity conditions. International Journal of Agriculture: Research and Review, 2 (5): 573-579.

3. Ashraf M., Akram N. A., Arteca R. N., Foolad M. R. 2010. The physiological, biochemical and molecular roles of brassinosteroids and salicylic acid in plant processes and salt tolerance. Critical Reviews in Plant Sciences, 29 (3): 162-190. https://doi.org/10.1080/07352689.2010.483586

4. Ashraf M., Ali Q. 2008. Relative membrane permeability and activities of some antioxidant enzymes as the key determinants of salt tolerance in canola (Brassica napus L.). Environmental and Experimental Botany, 63: 266-273. https://doi.org/10.1016/j.envexpbot.2007.11.008

5. Ashraf M., McNeilly T. 2004. Salinity tolerance in Brassica oilseeds. Critical Reviews in Plant Sciences, 23 (2): 157-174. https://doi.org/10.1080/07352680490433286

6. Athar H., Ashraf M., Wahid A., Jamil A. 2009. Inducing salt tolerance in canola (Brassica napus L.) by exogenous application of glycinebetaine and proline: response at the initial growth stages. Pakistan Journal of Botany, 41 (3): 1311-1319.

7. Banuelos G. S., Dhillon W. S., Banga S. S. 2013. Oilseed Brassica. Singh B. P. (ed). Biofuel crops: production, physiology and genetics, p. 339-368. https://doi.org/10.1079/9781845938857.0339

8. Benzie I. F. F., Strain J. J. 1999. Ferric reducing antioxidant power assay: direct measure of total antioxidant activity of biological fluids and modified version for simultaneous measurement of total antioxidant power and ascorbic acid concentration. Methods in Enzymology, 299: 15-27. https://doi.org/10.1016/S0076-6879(99)99005-5

9. Cruz de Carvalho M. H. 2008. Drought stress and reactive oxygen species: production, scavenging and signaling. Plant Signal and Behavior, 3 (3): 156-165. https://doi.org/10.4161/psb.3.3.5536
10. Dai Q. L., Chen C., Feng B., Liu T. T., Tian X., Gong Y., Sun Y., Wang J., Du S. Z. 2009. Effects of $\mathrm{NaCl}$ treatment on the antioxidant enzymes of oilseed rape (Brassica napus L.) seedlings. African Journal of Biotechnology, 8 (20): 5400-5405.

11. Espin J. C., Soler-Rivas C., Wichers H. J. 2000. Characterization of the total free radical scavenger capacity of vegetable oils and oil fractions using 2,2-diphenyl-1picrylhydrazyl radical. Journal of Agricultural and Food Chemistry, 48: 648-656. https://doi.org/10.1021/jf9908188

12. FAO. 2013. FAOSTAT. Food and Agriculture Organization of Unated Nation $<$ http://faostat.fao.org/>.

13. Foyer C. H., Noctor G. 2009. Redox regulation and photosynthetic organisms: signaling, acclimation, and practical implications. Antioxidants and Redox Signaling, 11: 861-905. https://doi.org/10.1089/ars.2008.2177

14. Giannopolitis C. N., Ries S. K. 1977. Superoxide dismutases. I. Occurrence in higher plants. Plant Physiology, 54: 309-314. https://doi.org/10.1104/pp.59.2.309

15. Halliwell B., Gutteridge J. M. C. 1989. Free radicals in biology and medicine. London, UK.

16. Hampton J. G., Tekrony D. M. (eds.). 1995. Handbook of vigour test methods. International Seed Testing Association, Zurich, Swizerland, chapter 3, p. 35-50.

17. Hasanuzzaman M., Nahar K., Fujita M., 2013. Plant response to salt stress and role of exogenous protectants to mitigate salt-induced damages. Ahmad Azooz M. M., Prasad M. N. (eds.). Ecophysiology and responses of plants under salt stress, p. $25-87$. https://doi.org/10.1007/978-1-4614-4747-4_2

18. ISTA. 2015. International Rules for Seed Testing. International Seed Testing Association, Zurich, Switzerland.

19. Jalali-e-Emam S. M. S., Alizadeh B., Zaefizadeh M., Zakarya R. A., Khayatnezhad M. 2011. Superoxide dismutase (SOD) activity in $\mathrm{NaCl}$ stress in salt-sensitive and salt-tolerance genotypes of colza (Brassica napus L.). Middle-East Journal of Scientific Research, 7 (1): 7-11.

20. Kato M., Shimizu S. 1987. Chlorophyll metabolism in higher plants. VII. Chlorophyll degradation in senescing tobacco leaves; phenolic-dependent peroxidative degradation. Canadian Journal of Botany, 65: 729-735. https://doi.org/10.1139/b87-097

21. Kumar V., Sahai V., Bisaria V. S. 2011. High-density sporeproduction of Piriformospora indica, a plant growthpromoting entophyte, by optimization of nutritional and cultural parameters. Bioresource Technology 102 (3): 3169-3175. https://doi.org/10.1016/j.biortech.2010.10.116

22. Miljus-Djukic J., Stanisavljevic N., Radovic S., Jovanovic Z., Mikic A., Maksimovic V. 2013. Differential response of three contrasting pea (Pisum arvense, $P$. sativum and P. fulvum) species to salt stress: assessment of variation in antioxidative defence and miRNA expression. Australian Journal of Crop Science, 7 (13): 2145-2153.

23. Mittal S., Kumari N., Sharma V. 2012. Differential response of salt stress on Brassica juncea: photosynthetic performance, pigment, proline, D1 and antioxidant enzymes. Plant Physiology and Biochemistry, 54: 17-26. https://doi.org/10.1016/j.plaphy.2012.02.003

24. Munns R. 2005. Genes and salt tolerance: bringing them together. New Phytologist, 167: 645-663. https://doi.org/10.1111/j.1469-8137.2005.01487.x

25. Ng T. B, Liu F., Wang Z. T. 2000. Antioxidative activity of natural products from plants. Life Science, 66: 709-723. https://doi.org/10.1016/S0024-3205(99)00642-6

26. Popovic B. M., Stajner D., Zdero Z., Orlovic S., Galic Z. 2013. Antioxidant characterization of oak extracts combining spectrophotometric assays and chemometrics. Scientific World Journal, 2013: 134656. https://doi.org/10.1155/2013/134656

27. Prakash A. 2001. Antioxidant activity. Medallion Laboratories Analytical Progress, 19 (2): 1-4. 
28. Punitha S. C., Rajasekaran M. 2011. Antioxidant mediated defence role of Wedelia calendulacea herbal extract against $\mathrm{CCl}_{4}$ induced toxic hepatitis. Journal of Applied Pharmaceutical Science, 1: 111-115.

29. Rameeh V., Cherati A., Abbaszadeh F., 2012. Salinity effects on yield, yield components and nutrient ions in rapeseed genotypes. Journal of Agricultural Science, 57 (1): 19-29. https://doi.org/10.2298/JAS1201019R

30. Shahbaz M., Ashraf M. 2013. Improving salinity tolerance in cereals. Critical Reviews in Plant Sciences, 32 (4): 237-249. https://doi.org/10.1080/07352689.2013.758544

31. Shahbazi E. S., Arzani A., Saeidi G. 2011. Effects of $\mathrm{NaCl}$ treatments on seed germination and antioxidant activity of canola (Brassica napus L.) cultivars. Bangladesh Journal of Botany, 41 (1): 67-73. https://doi.org/10.3329/bjb.v40i1.8000

32. Smith S. L., Thelen K. D., MacDonald S. J. 2013. Yield and quality analyses of bioenergy crops grown on a regulatory brownfield. Biomass and Bioenergy, 49: 123-130. https://doi.org/10.1016/j.biombioe.2012.12.017

33. Stajner D., Orlovic S., Popovic B. M., Kebert M., Stojnic S., Klasnja B. 2013. Chemical parameters of oxidative stress adaptability in beech. Journal of Chemistry, 2013: 1-8. https://doi.org/10.1155/2013/592695

34. Tanou G., Molassiotis A., Diamantidis G. 2009. Induction of reactive oxygen species and necrotic death-like destruction in strawberry leaves by salinity. Environmental and Experimental Botany, 65 (2-3): 270-281.

https://doi.org/10.1016/j.envexpbot.2008.09.005
35. Tavakkoli E., Rengasamy P., McDonald G. K. 2010. High concentrations of $\mathrm{Na}^{+}$and $\mathrm{Cl}^{-}$ions in soil solution have simultaneous detrimental effects on growth of faba bean under salinity stress. Journal of Experimental Botany, 61 (15): 4449-4459.

https://doi.org/10.1093/jxb/erq251

36. Tayefi-Nasrabadi H., Dehghan G., Daeihassani B., Movafegi A., Samadi A. 2011. Some biochemical properties of guaiacol peroxidases as modified by salt stress in leaves of salt-tolerant and salt-sensitive safflower (Carthamus tinctorius L.cv.) cultivars. African Journal of Biotechnology, 10 (5): 751-763.

37. Turkan I., Demiral T. 2009. Recent developments in understanding salinity tolerance. Environmental and Experimental Botany, 67: 2-9. https://doi.org/10.1016/j.envexpbot.2009.05.008

38. Vernoux T., Wilson R. C., Seeley K. A., Reichheld J. P., Muroy S., Brown S., Maughan S. C., Cobbett C. S., Van Montagu M., Inze D., May M. J., Sung Z. R. 2000. The root meristem less $1 /$ cadmium sensitive 2 gene defines a glutathione-dependent pathway involved in initiation and maintenance of cell division during postembryonic root development. The Plant Cell, 12 (1): 97-110. https://doi.org/10.1105/tpc.12.1.97

39. Zare S., Paknyat H. 2012. Changes in activities of antioxidant enzymes in oilseed rape in response to salinity stress. International Journal of Agriculture and Crop Sciences, 4 (7): 398-403.

ISSN 1392-3196 / e-ISSN 2335-8947

Zemdirbyste-Agriculture, vol. 104, No. 3 (2017), p. 249-258

DOI $10.13080 / \mathrm{z}-\mathrm{a} .2017 .104 .032$

\title{
Druskos poveikis rapsų daigų gyvybingmui ir antioksidaciniam aktyvumui
}

\author{
D. Jovičić ${ }^{1}$, D. Štajner ${ }^{2}$, B. Popović ${ }^{2}$, A. Marjanović-Jeromela ${ }^{1}$, Z. Nikolić ${ }^{1}$, \\ G. Petrović1, R. Ždero-Pavlović ${ }^{2}$
}

${ }^{1}$ Serbijos lauko augalų ir daržovių institutas

${ }^{2}$ Novi Sad universitetas, Serbija

\section{Santrauka}

Tyrimo tikslas - nustatyti druskos $(\mathrm{NaCl})$ sukelto streso įtaką trijų veislių - 'Banacanka', 'Jasna' ir 'Kata', rapsams (atitikmuo - sejjamajam rapsui, Brassica napus L.). Atsakas ị druskos poveikị vertintas pagal antioksidacinius fermentus superoksido dismutazę (SOD) ir 2-metoksifenolio gvajakolo peroksidazę (GPX), sumažejusią glutationo (GSH) koncentraciją, lipidų peroksidacijos (LP) intensyvumą, radikalų surišimo difenil-1-pikrilhidrazilo hidratu (DPPH-RSC) gebą, hidroksilo radikalų surišimą ir $\mathrm{Fe}^{3+}$ redukavimo ị $\mathrm{Fe}^{2+}$ testą (FRAP).

Rapsų sèklos septynias dienas daigintos trijų koncentracijų - 0, 100, 150 ir $200 \mathrm{mmol} \mathrm{dm}^{-3} \mathrm{NaCl}$ tirpale. Jų gyvybingumas buvo vertintas laboratorijoje pagal daigumą, daigų ir šaknų ilgị, taikant sẻklų pagreitinto senèjimo testa.

Dèl druskos poveikio visų trijų veislių rapsų daigų padidèjo lipidų peroksidacija ir sumažèjo GPX aktyvumas. Nustatyta, kad veikiant didžiausios koncentracijos $\mathrm{NaCl}$ tirpalu, pažeidžiamiausi buvo veislès 'Banacanka' augalai, kurių lipidų peroksidacija padidèjo $237 \%$, lyginant su kontroliniais. Veikiant skirtingos koncentracijos $\mathrm{NaCl}$ tirpalu buvo indukuotas visų trijų veislių rapsų augalų SOD aktyvumas. Taip pat buvo indukuota antioksidaciné geba, ivertinta pagal FRAP, DPPH-RSC ir 'OH radikalus; esant didžiausios koncentracijos $\mathrm{NaCl}$ tirpalui, ypač sustiprejo veislès 'Jasna' rapsų FRAP (282 \%). Dèl druskos poveikio sumažèjo visų tirtų veislių rapsų sėklų daigumas, daigų ir šaknų ilgis.

Pagal didžiausią SOD aktyvumą ir daugiausia sukauptų antioksidantu veislès 'Jasna' rapsai buvo labiausiai prisitaikę prie druskos sukelto streso. Be to, šis tyrimas rodo, kad kai kurie antioksidacinès gebos rodikliai gali būti naudingi biocheminiai žymekliai atrenkant druskingumui atsparias rapsų veisles.

Reikšminiai žodžiai: antioksidaciniai fermentai, Brassica napus, daigumas, druskos sukeltas stresas, lipidų peroksidacija, pagreitintas senėjimas. 